\title{
ADDRESSING 21'TT CENTURY COMMUNICATION SKILLS: SOME EMERGING ISSUES FROM EIL PEDAGOGY \& INTERCULTURAL COMMUNICATIVE COMPETENCE
}

\author{
Athriyana S. Pattiwael \\ Universitas Kristen Satya Wacana, Indonesia \\ (athriyana.pattiwael@staff.uksw.edu)
}

Received: $14^{\text {th }}$ September 2016; Revised: $17^{\text {th }}$ November 2016; Accepted: $28^{\text {th }}$ December 2016

\begin{abstract}
$21^{\text {st }}$ Century Skills has attracted the attention of various education experts, practitioners, school management, teachers and educational managers in ASEAN countries, including Indonesia. A number of activities in terms of seminars and workshops have been held by a wide range of institutions to address this framework in terms of how to align it to the curriculum and how to integrate it into classroom activities. Regarding communication skills, Partnership for $21^{\text {st }}$ Century Skills defines $21^{\text {st }}$ Century Communication Skills - among the other five definitions - as communicating effectively in diverse environments (including multilingual and multicultural). Realizing that this framework was developed in the American context for their national education purposes, it is imperative for various parties, including teachers and practitioners of English as a Foreign Language, to contextualize it by considering both local and regional contexts. As a minute contribution to the effort of contextualizing the framework, this paper will address some emerging issues in developing the instructional materials framed by the pedagogy of English as an International Language and Intercultural Communicative Competence.
\end{abstract}

Key Words: $21^{\text {st }}$ century communication skills; intercultural communicative competence

\section{ABSTRAK}

Keterampilan Abad ke-21 telah menarik perhatian beragam kalangan dari pakar pendidikan, praktisi, pengelola sekolah, guru sampai para manajer institusi pendidikan di negara-negara ASEAN, termasuk Indonesia. Serangkaian kegiatan termasuk seminar dan workshop telah diselenggarakan oleh berbagai institusi untuk membedah kerangka kerja ini dalam hal Tentang keterampilan berkomunikasi, Partnership for $21^{\text {st }}$ Century Skills mendefinisikan keterampilan Komunikasi Abad ke-21 -di antara lima definisi lainnya- sebagai kemampuan berkomunikasi secara efektif di berbagai lingkungan (termasuk multibahasa dan multikultural). Menyadari bahwa kerangka kerja ini dikembangkan dalam konteks Amerika untuk tujuan pendidikan nasional mereka, maka sangatlah penting bagi berbagai pihak, termasuk guru dan praktisi bahasa Inggris sebagai bahasa asing, untuk mengkontekstualisasikannya dengan mempertimbangkan konteks lokal dan regional. Sebagai kontribusi kecil terhadap upaya kontekstualisasi tersebut, tulisan ini akan membahas beberapa isu yang muncul dalam pengembangan bahan ajar yang dibingkai oleh pedagogi Bahasa Inggris sebagai Bahasa Internasional dan Kompetensi Komunikasi Antarbudaya.

Kata Kunci: keterampilan abad ke-21; kompetensi komunikasi antar-budaya

How to Cite: Pattiwael, A., S. (2016). Addressing 21 ${ }^{\text {st }}$ Century Communication Skills: Some Emerging Issues from Eil Pedagogy \& Intercultural Communicative Competence. IJEE (Indonesian Journal of English Education), 3(2), 158-170 doi:10.15408/ijee.v3i2.3164.

Permalink/DOI: http://dx.doi.org/10.15408/ijee.v3i2.3164 


\section{INTRODUCTION}

Communication in $21^{\text {st }}$ century is characterized by the nature of the communication itself which tends to be more and more globalized. Flew (2008) describes that we are moving from the typical model of $20^{\text {th }}$ century communication characterized by oneto-many, top-down mass towards $21^{\text {st }}$ century communication model that is more open, interactive, multidimensional and participatory. In relation to the pattern of globalized communication, Goldsmith (1998) identifies two possible emerging interrelated trends, namely the sharp increase of the possibility to communicate instantly and massively across the world and the ability to create communities of choices. The increase is driven by several factors, such as global trade, media development and evolution, technology enhancement, international education, the advancement in scientific exchange and international tourism.

The fact that $21^{\text {st }}$ century communication drives an impressive international communication presents some opportunities. The opportunities for learning will be greater due to the massive available communication. Goldsmith (2008) argues that $21^{\text {st }}$ century communication provides the potential for "global connectedness".
This implies that we will have "the opportunity to interact in a way that leads to the rapid and positive evolution of our species" (p. 2). Furthermore, 21 2 st century communication creates a platform for collaboration across sectors and entities. It also creates room and access for local issues to be shared among the interactants.

On the other hand, some challenges are also presented by the progressive 21 $1^{\text {st }}$ century communication. Communication becomes both more difficult and more necessary since diversity and change are unavoidable. The diverse setting of communication will require more competent, strategic and articulate interactants. Common conception of how communication take places is no longer adequate and to some extent might be misleading. The mechanical sender-receiver model of communication obscures complex relations and process in globalized communication (Miller, 1996).

The relevant underlying point here is English has gained global currency in the majority of $21^{\text {st }}$ century communication process. Jenkins and Murata (2009) explicate that within the setting of communication where English has gained global currency, the interactants, who come from different 
linguistic and cultural background, would most likely choose English as the means of communication since they cannot help using a language of their choice. By Smith's definition (1976, cited in McKay, 2002), English here gains the status as an International language (EIL) in which it is used by people of different nations to communicate with one another.

The use of EIL itself in $21^{\text {st }}$ century communication activities presents some dynamics. The dynamics is best described by adopting Canagarajah's (2006) features of postmodern globalization. Postmodern globalization captures the dynamics of English use beyond Kachru's perspectives of various role English serves in different parts of the world (the three concentric circles) that tends to segment the English use and variety in each of the circles. Postmodern globalization facilitates the fact that communication activities occurs across the circles. Varieties of English exist in the outer circle start to leak outside the circles. Kachruvian model that views each variety considered to be valid and relevant within its national identity is being challenged. Indian English is now relevant when the Indians have to conduct their business activities with business counterparts from other countries. The speakers of English belong to inner circle are expected to at least have receptive skills in different Englishes they might find in their business transaction with outsourced companies in different countries.

The dynamics in expanding circle countries, such as China, Vietnam, Philippines, Brazil, etc. presents another picture of $21^{\text {st }}$ century communication activities. Canagarajah (2006) and Matsuda (2012) observe the increasing currency of English in these aforementioned countries. The speakers do not only use English for international relations and communication, but also use it for intranational purposes.

Furthermore, 21 $1^{\text {st }}$ century communication dynamics present another fact that English is used quite intensively and extensively on daily basis life by the speakers who live in many nonnative English contexts. English is progressively used as an international language both among native and nonnative speakers and among nonnative and nonnative speakers (Acar, 2009). Seidlhofer (2003) affirms that within these dynamics, English is used both by plurilingual and monolingual people. The following essential notion here is when it is used either plurilingually or monolingually, English has taken various forms reflecting the linguistic and cultural 
backgrounds of its speakers (Acar, 2009).

The aforementioned dynamics indicate that the communicative needs are changing at the present time (Canagarajah, 2006). It means that the nature of $21^{\text {st }}$ century communication is not only rich and complex in term of linguistic features (Acar, 2009), but also on the basis of cultural norms and values. The dynamics call for the need of reorienting the notion of becoming competent communicators of English. In the efforts of either adapting or adopting 21 ${ }^{\text {st }}$ Communication Skills to our English teaching and learning, this paper suggests that $21^{\text {st }}$ Communication Skills should not only be perceived (and later be approached) from the perspective of using English as in the interaction among native speakers in which native speakerism and native likeness are the standard of usage and level of acceptance (Trudgill \& Hannah, 1994). Rather, these skills should also be contextualized in the reality of intercultural communication by embracing the fact that English as an International Language is used to communicate with people from different nations, languages and cultural backgrounds.

Embracing the fact of EIL in the effort of developing students' $21^{\text {st }}$ CS brings the implications to our pedagogical decisions. Teaching English as EIL requires English learning and teaching practices and its agents to revisit the goal of learning English. The present ELT classrooms practices that still learn English for interaction with native speakers through adopting native speaker communicative competence as a goal of learning and learning the cultural conventions of the native speaker are challenged (Canagarajah, 2006; Matsuda, 2012; McKay, 2002, 2003; Alptekin, 2002; Acar, 2009; Pattiwael, 2014). The revisit is becoming more imperative considering the evolving role of English itself and the reality of cross-cultural communication in international communication contexts. These conditions present a new set of communicative need, determine what communicative competencies needed and later determine what kind of teaching-learning materials and classroom activities that teachers should take into account.

\section{COMMUNICATIVE COMPETENCE REQUIRED IN 21 ${ }^{\text {sT }}$ CENTURY COMMUNICATION}

What communicative competence should we provide to our students to enable them to participate in these highly cross cultural and the international communication? 
Canagarajah (2006) describes the profile of the expected communicators in this communication setting. 21 $1^{\text {st }}$ century communicators are expected to be multi-dialectical. It is unavoidable to be multi-dialectical since $21^{\text {st }}$ century communication requires those who participate in it to "constantly shuttle between different varieties and communities" (p. 5). Being a multidialectical communicator does not mean that being productive in all varieties of English. Yet, it enables the communicators to be capable of negotiating diverse varieties to ensure the communication process runs effectively. Furthermore, Canagarajah (2006, p.233) considers "passive competence to understand new varieties" as also part of multidialectical competence. To this point of communicative competence, all varieties are considered important and significant in building up communicator's linguistic and cultural repertoire and to some extent enriching it.

Considering the fact that $21^{\text {st }}$ century communication also takes place across cultures, the expected communicators in this communication context are also expected to be interculturally competent. Byram's (2000) framework of intercultural communicative competence provides the portrayal of this typical communicators. When communicating cross-culturally, the communicators with some degree of intercultural competence are able to see relationships between different cultures and are able to mediate. The ability to mediate here involves the interpretation of each culture in terms of the other, either for themselves or for other people. Furthermore, the communicators are described as the party whose critical or analytical understanding of (parts of) their own and other cultures. The state of being critical or analytical is constructed when there is a consciousness in the side of communicators that their perspectives and the ways of thinking are not naturally fabricated, yet culturally determined.

McKay (2002) enriches Byram's framework by elaborating it more into the setting of EIL. The emphasis of being competent communicators (in the context of bilingual users in the outer circle) is given more on pragmatic and rhetorical competence. McKay (2002) explicates that achieving pragmatic competence involves the ability to understand the illocutionary force of an utterance, that is what a speaker intends by making it which is cultural in its nature. It also covers the ability to know which form for expressing a 
particular meaning is most appropriate for a particular context. The selection of form itself is culturally basis for selecting the inappropriate form to the context may lead to cross-cultural misunderstanding. The underlined intercultural competence here is developing the awareness that pragmatic rules can differ significantly across cultures.

Alptekin (2002) strengthens the notion by describing intercultural competence as the ability to communicate effectively with others from different cultural backgrounds. This ability is accompanied with an awareness of differences among cultures and with strategies for coping with such differences. In the setting of EIL, Nunn (2007, cited in Acar, 2009) joins the line by emphasizing that intercultural competence requires the knowledge of cultures involve in the communication setting to facilitate the successful communication. Within this setting, being intercultural competent communicators involve the ability to adjust to unpredictable multicultural situations.

\section{EMERGING ISSUES IN DEVELOPING MATERIALS TO ADDRESS 21 ${ }^{\text {ST }}$ COMMUNICATION SKILLS WITHIN THE FRAME OF EIL AND ICC}

Considering the profile of the expected communicator in the $21^{\text {st }}$ century, there are some emerging issues that teachers might take into account in material development process. The balanced focus of teaching and learning is the first emerging issue here. The focus of teaching and learning should also be on developing proficiency in pragmatics, rather than focus solely on developing proficiency in grammar or in abstract linguistic features as means of context to prepare the students to be able to "shuttle between English varieties and speech communities" (Canagarajah, 2006, p. 5).

Embracing this focus would lead the teachers to include "sociolinguistic skills of dialect differentiation, code switching, style shifting, interpersonal communication, and discourse strategies" (McKay, 2005 in Canagarajah, 2006, p.233). It is essential that students are informed to the fact that within the real intercultural and international communication setting, certain breakdown in communication settings could not be perceived as completely miscommunication. Rather, the breakdown could be considered as a 
creative rhetorical act since in order to facilitate communication the interlocutors might work on convergence strategies, but they could also adopt the divergence strategies to create distance between them (Jenkins, 2006).

The second emerging issues here is developing stronger language awareness among students. The setting of $21^{\text {st }}$ communication necessitates greater needs to engage with multiple English varieties. Canagarajah (2006) suggests that developing competence in only one dialect or language system would not be a tactful step to take in developing the awareness. He argues that the communicators should develop the cognitive abilities to negotiate multiple dialects as they shuttle between communities and varieties. The awareness could be cultivated by assisting students to process the underlying system in the varieties that they encounter in social interactions. Exposing to various social interactions, it is expected that when they were exposed to new varieties or dialects, students would gradually cultivate intuitive skills to develop relative communicative competence according to their needs. It is expected that as the prospective 21 $1^{\text {st }} \quad$ century communicators, students were facilitated with the progressive ability to discern the structure, pattern and rules work within particular varieties or dialects.

Seidlhofer (2004), who works extensively in the area of lingua franca core features, encompasses the concept of developing language awareness by underlying the principle of lingua franca core. Working with this principle, it is foundational to help students to find the fact that in such multilingual contexts, particular sound and grammatical structured classified as norm in a dominant variety may not contribute as the facilitating factors in communication process. The facts may reveal that in order to facilitate communication process, the communicators might have to deviate from these norms.

Setting the teaching objective(s) that serves the purpose of developing students' intercultural communicative competence is the next emerging issue. To ensure the elements of intercultural competence were facilitated well during the teaching and learning process, a set of clear teaching objective should be formulated. Byram (2001), in his work in 1997, proposes a valuable paradigm on defining, teaching and assessing intercultural communicative competence that has been exploited and referred to by various researchers in the field of intercultural communicative 
competence. Briefly, he contends that intercultural competence involves five elements namely attitudes, knowledge, skills of interpreting and relating, skills of discovery and interaction and critical cultural awareness/political education.

Byram's model of different dimensions of intercultural communicative competence then were summarized by Nault (2006, cited in Nunn, 2011). The dimensions cover the area of attitudes, knowledge, skills of interpreting and relating, skills of discovery and interaction, and cultural awareness. Nault suggests that Byram's model can be adapted as teaching objectives as follow: (1) Attitudes. Learners should be curious, openminded and flexible, or ready "to suspend disbelief" about others' cultures. (2) Knowledge. Learners should understand "social groups and their products and practices" and "the general processes of societal and individual interaction" in their own and foreign countries. (3) Skills of interpreting and relating. Learners should be able "to interpret a document or event from another culture" in relation to their own cultural perspective. (4) Skills of discovery and interaction. Learners should be able "to acquire new knowledge of a culture and cultural practices" and "operate knowledge, attitudes and skills under the constraints of real-time communication and interaction". (5) Critical cultural awareness. Learners should be able "to evaluate critically and on the basis of explicit criteria perspectives, practices and products" in their own and others' cultures and countries.

When English is used in an international setting, it involves crossing borders as individuals interact in cross-cultural encounter that highly demands intercultural competence. The nature of this typical communication which is highly cultural on its basis leads the teachers to bring culture into the classroom. The attention is drawn to which and how culture should be presented into the classrooms, as the next emerging issue in developing materials. Cortazi and Jin (1999) classifies the textbook and teaching materials reflecting cultures into three patterns, namely source culture materials, target culture materials and international target cultures materials.

Focusing on enhancing students' intercultural communicative competence, international target culture materials present some benefits, next to some disadvantages. International target culture materials use and incorporate a great variety of cultures in English and non-English-speaking countries around the world in the set of learning materials. The opportunities 
for the students to experience reflective interpretation of their own culture (C1) and the culture of others (C2) are possible when they come into direct contact with other cultures. The experiences of coming into contact involve the students in an objective and subjective reflection of $\mathrm{C} 1$ and $\mathrm{C} 2$. The reflection provides them platform from which they must choose their own meanings that best reflect their personal perspectives. Furthermore, the teachers through effective instructional activities may aid students' effort in finding possible manners in which English is used effectively to communicate with different types of communities for various international purposes. Providing the students with the opportunity in which they are able to adapt to different types of communities is considered principal to Nunn (2011). He argues that EIL users do not operate in homogenous, single speech communities. Therefore, they need to be able to communicate within different kinds of communities.

The last emerging issues considered significant to be taken into account when developing materials is how teachers facilitate the process of developing students' intercultural communicative competence. This paper perceives English classrooms as a setting and/or context where the students extend their process of acquiring new cultures and be encouraged to follow this process of acquiring by self-reflection and meaning modification. Learning about various culture-based communication contexts within this setting is more than just transferring the information between cultures. It requires the students to consider their own culturebased communication practices in relation to other (cultural) practices. McKay (2002) strengthens this notion by stating that the process of learning about another culture, including communication practices, entails reflection on one's own culture as well as the other cultures.

Teacher's role in facilitating this phase is imperative. Brown (2000) describes what sort of process encountered by the students as they deal with various cultures presented in the class. The students experience feelings of being frustrated because of the failure mixed with the fearful anticipation of entering a new group. They suffer from feelings of social uncertainty or dissatisfaction as the result of being exposed and/or being in contact with new cultures. Brown (2000) explains that this process is a significant aspect of the relationship between language learning and attitude toward the foreign culture and coins 
the process as the concept of anomie. This is the stage where the students find themselves neither bound firmly to their native culture nor fully adapted to the second culture.

The teacher plays significant role in assisting the students who are on the phase of anomie. They bridge the gap by supporting the students to establish their "third place". Kramsch (1993) describes this "third place" as the place where the students position themselves between their first culture (C1) and the second culture (C2). As a process, it is described as the process of involving the students in an objective and subjective reflection of their $\mathrm{Cl}$ and C2. The reflection is imperative as an entry into the process of selecting and constructing their meanings that best reflect their personal perspectives. These personal perspectives are the results of comparing and contrasting between cultures. The process emphasizes the importance of individual interpretations of certain cultural practices and/or perspectives. This individual interpretation might lead the students to question or even further to challenge and debunk stereotypes around them.

The reflective activity as the center of establishing the third place needs to consider two underlying points here. Firstly, establishing a sphere of inter-culturality is the essential part of the reflective activity. Kramsch (1993) emphasizes that the more reflective activity the students have, the clearer relationship between different cultural practices, including communication practices, they will find. The second crucial point relates to the focus of bringing and teaching culture-based communication practices to the class. The teachers are suggested to design the materials with the instructional activities that go beyond the presentation of culture-based communication facts or practices only. The instructional activities should bring the students arrive to the point where they understand what seems to be the 'foreignness' of the other communication practices. The students are facilitated to find the macro features of the practices such as specific cultural values and attitudes behind certain communication practices. The findings might appear as either differences or similarities. The differences should be deliberately made visible to the students. Kramsch (1993) claims that by identifying the difference the students are able to understand their own culture-based communication practices better and see how different cultures interact between one to another. The identification of differences would also help the students to see the unique and distinct characteristics of different 
communication practices. By increasing students' awareness of culture-based communication differences, their sensitivity and accommodation skill can be developed. Besides, the awareness would contribute to their cultural repertoire later be accessed and revisited when they shuttle between various culture-based communication settings with different communities and/or dialects.

\section{CONCLUSION AND SUGGESTION}

$21^{\text {st }}$ century communication practices at the present time shape the direction and the needs in teaching and learning English. The fact that the majority of $21^{\text {st }}$ communication activities are highly intercultural in its nature present a strong call to embrace intercultural communicative competence in ELT classrooms' efforts to address $21^{\text {st }}$ communication skills. Framing the efforts with EIL pedagogy and the framework of Intercultural Communicative Competence assist the teachers and the practitioners to revisit the concept of communicative competence ELT classrooms aim at. Furthermore, the framing would help the teacher to be more well-informed in their instructional decisions by considering some emerging issues in developing the materials. It is expected that our ELT classrooms would provide more opportunities for the students to be effective communicators in any possible cross-cultural international communication.

\section{REFERENCES}

Acar, A. (2009). On EIL competence. English as an International Language Journal, 5 (Special Edition), 11-26.

Alptekin, C. (2002). Towards intercultural communicative competence. ELT Journal, 56 (1), 57-64.

Brown, J. D. (2000). Principles of language learning and teaching, $4^{\text {th }}$ ed. New York: Longman Inc.

Byram, M. (2000). Assessing intercultural competence in language teaching. Sprogforum, 16 (1), 8-13.

Byram, M., Nichols, A., \& Steven, D. (2001). Developing intercultural competence in practice. Clevedon: Multilingual Matters.

Canagarajah, S. (2006). Changing communicative needs, revised assessment objectives: testing English as an international language. Language Assessment Quarterly, 3(3), 229- 242. 
Cortazi, M., \& Jin, J. (1999). Cultural mirrors: materials and methods in the EFL classroom. In Eli Hinkel (Eds), Culture in second language teaching and learning. Cambridge: The Press Syndicate of the University of Cambridge.

Center for Communication in Science, Technology and Management. (1996, August). Communication in the 21st Century: The Original Liberal Art in an Age of Science and Technology. North Carolina: Carolyn Miller.

Flew, T (2008, March). Communication for the 21st Century. Paper presented at the meeting of Society of Business Communicators, Brisbane.

Goldsmith, M. (1998). Global communication and communities of choice. In Beckhard, R, Goldsmith, $\mathrm{M}$ and Schubert, F.R (Eds), The drucker foundation: The community of the future. San Francisco: Jossey-Bass.

Jenkins, J., \& Murata, K. (2009). Global Englishes in Asian contexts; Current and future debate. New York: Palgrave MacMillan Publishing Ltd.
Jenkins, J. (2006). The spread of English as an international language: A testing time for testers. ELT Journal, 60, 51-60

Kramsch, C. (1993). Context and culture in language teaching. Oxford: Oxford University Press.

Language Policy Division, Council of Europe. (2003). A Concept of International English and Related Issues: From 'Real English' to 'Realistic English'. Strasbourg: Barbara Seidlhofer.

Matsuda, A. (2012). Teaching English as an international language. In Matsuda, A (Ed), Principles and practices of teaching English as an international language. New York: Multilingual Matters.

McKay, S. (2002). Teaching English as an International Language. Oxford: Oxford University Press.

McKay, S. (2003). Toward an appro priate EIL pedagogy: reexamining common ELT assumptions. International Journal of Applied Linguistics, 13 (1), 1-22.

Nunn, R. (2011). From defining to developing competence in EIL and intercultural communication. English as an International Language Journal, 6 (1), 21-46. 
Pattiwael, A. (2014). Towards an Trudgill, P., \& Hannah, J. (1994). intercultural competence in the International English (3rd ed.). World English era: Some London: Edward Arnold. emerging issues and considerations regarding culture in the classrooms. In Pandian, A., Ling, C. L., Lin, D.T., Muniandy,J., Choo, L.B \& Hiang, C. T (Eds), Language Teaching and Learning: New Dimensions and Interventions (pp.26-42). Newcastle upon Tyne: Cambridge Scholars Publishing. 